\title{
FILOSOFI PERTUNJUKAN WAYANG PURWA
}

\author{
Djoko Sulaksono \\ Universitas Sebelas Maret Surakarta (UNS) \\ Jl. Ir. Sutami No. 36 A (+62-271) 646624 Surakarta 57126 \\ E-mail: ciptaningmintaraga@yahoo.com \\ HP. +6285292829999
}

\begin{abstract}
Purwa Puppet (Wayang Purwa) is one of traditional art which has existed for thousand years. It is internalized in man's life. The puppet show describes the life cycle of a man; from the first day until he died. It is showed implicitely by the gunungan, when it is moved by the dalang until it is embedded for the last time (tancep kayon).

Abstrak: Wayang purwa adalah salah satu kesenian tradisional yang sudah berumur ribuan tahun sehingga sudah mendarah-daging pada kehidupan masyarakat Jawa. Pertunjukan bayang-bayang ini menggambarkan kehidupan manusia dari lahir sampai meninggal. Semua digambarkan secara tersirat mulai dari gunungan digerakkan sampai dengan gunungan ditancapkan untuk yang terakhir kali atau tancep kayon.
\end{abstract}

Kata Kunci: wayang, profetik, Islam, makna filosofis, kehidupan.

\section{A. Pendahuluan}

Pengembangan karakter atau kebudayaan suatu bangsa tidak pernah dapat melepaskan diri dari nilai-nilai tradisi yang telah mendasari dan membesarkannya. Kelahiran karya sastra diprakondisi oleh kehidupan sosial budaya tempat pengarang hidup, sehingga sikap dan pandangan hidup pengarang terhadap masalah yang diceritakan dalam karyanya juga mencerminkan kehidupan sosial budaya masyarakatnya (Chatman dalam Nurgiyantoro, 1998: 1). Seperti di Indonesia, khususnya Jawa, wayang merupakan tradisi dan budaya yang telah mendasari dan berperan besar dalam membentuk karakter dan eksistensi bangsa Indonesia, khususnya yang beretnis Jawa.

Dalam pertunjukan wayang dibicarakan berbagai masalah kehidupan manusia dan kemanusiaan. Cerita wayang kulit dapat dipakai sebagai sumber pencarian nilai-nilai, karena di dalamnya terdapat berbagai macam ajaran dan nilai etis yang bersumber dari berbagai agama serta sistem filsafat dan etika (Amir, 1997: 16). Pertunjukan wayang purwa merupakan bentuk kesenian 
tradisional yang paling disukai masyarakat Indonesia, Jawa pada khususnya. Bagi masyarakat Jawa, cerita wayang telah menjadi salah satu sumber tontonan, tuntunan, dan tatanan. Nilai-nilai filosofis dan ajaran-ajaran yang terkandung di dalamnya adalah nilai-nilai luhur yang telah mampu melewati ujian dari waktu ke waktu. Sejak zaman dahulu sampai sekarang, pertunjukan wayang tidak pernah berhenti, padahal wayang sudah ada sejak ratusan tahun yang lalu. Hal ini terbukti dengan masih adanya pertunjukan wayang sampai sekarang. Walaupun sudah banyak perubahan jalan ceritanya, tetapi hal itu tidak mengurangi isi yang terkandung di dalamnya.

Tulisan ini berusaha untuk mengupas tentang filosofi wayang yang menjadi tontonan, tunt unan, dan tatanan bagi masyarakat Indonesia, khususnya masyarakat Jawa. Kisah-kisah dalam wayang sendiri dapat menjadi inspirasi sebagaimana Sunan Kalijaga berdakwah melalui wayang.

\section{B. Wayang dan Sastra Wayang}

Perkataan wayang mengandung berbagai pengertian, yakni gambaran tentang suatu tokoh, boneka, atau boneka pertunjukan yang berjalan berkalikali, lalu lalang, tidak tetap, samar-samar, remang-remang (Mulyono dalam Sutardjo, 2006: 49). Sebenarnya, kata 'wayang' berkaitan dengan kata hyang, yang berarti leluhur. Akar kata hyang adalah yang, maksudnya bergerak berkalikali, simpang siur, lalu lalang, melayang. Wayang dapat pula berarti suksma, roh, yang melayang, yang mengitar. Makna dan arti hyang dapat dirinci menjadi dua, yakni (1) sukma, roh, (2) orang telah meninggal (leluhur). Maka dari itu, dalam pertunjukan wayang purwa itu menghasilkan bayangan (wayangan) sehingga dinamakan wayang atau shadow play 'pertunjukan atau permainan bayangan' (Sutardjo, 2008: 58).

Wayang adalah sebuah kata bahasa Indonesia (Jawa) asli yang berarti bayang at au bayang-bayang yang berasal dari akar kata yang dengan mendapat awalan wa menjadi kata wayang. Kata-kata di dalam bahasa Jawa yang mempunyai akar kata yang dengan berbagai variasi vokalnya antara lain adalah layang, dhoyong, puyeng, reyong, yang berarti: selalu bergerak, tidak tetap, samar-samar dan sayup-sayup. Kata wayang, hamayang pada waktu dulu berarti: mempertunjukkan bayangan. Lambat laun menjadi pertunjukan bayang-bayang. Kemudian menjadi seni pentas bayang-bayang atau wayang (Sri Mulyono,1979: 51-52).

Sastra wayang adalah jenis sastra Jawa Kuna yang menampilkan kisah tokoh-tokoh wayang yang bersumber dari Ramayana, Mahabharata, dan Pustaka Raja Purwa. Jumlah sastra wayang sangat banyak. Sebagian gubahanya dalam 
bentuk tembang macapat dan selebihnya dalam bentuk (prosa). Selain kedua bentuk itu, naskah sastra wayang juga digubah dalam bentuk pakem pedhalangan yang berisi teks pedalangan lengkap yang terdiri at as narasi dalang, dialog tokoh wayang, sulukan, dan gendhing-gendhing pengiring yang disertai dengan sasmita-sasmita gendhing. Fungsi pakem pedalangan (pakem pedhalangan jangkep) sesungguhnya tidak untuk dinikmati sebagai bahan bacaan tetapi sebagai tuntunan teknis bagi para dalang dan terutama bagi para calon dalang. Pakem pedhalangan jangkep Dewasa ini juga dihasilkan dengan cara mentranskripsi seutuhnya rekaman pergelaran wayang. Transkripsi itu kemudian disunting dan diterbitkan. Naskah hasil transkripsi dapat dinilai sebagai bentuk transformasi sastra lisan. Selain pakem pedhalangan jangkep, ada pula teks lain yang berfungsi sebagai tuntunan para dalang, terutama dalam hal penguasaan lakon wayang, yaitu yang dikenal dengan sebutan pakem balungan. Isinya dari awal sampai akhir pergelaran wayang dalam pola yang sudah baku. Tiap adegan memuat nama tempat, tokoh-tokoh, yang tampil, dan inti pembicaraan ataupun persoalan yang terjadi dalam adegan tersebut. Meskipun uraiannya serba singkat, bagi dalang sudah cukup memadai sebagai sebagai pegangan untuk mempergelarkan lakon 'cerita' tertentu yang dipilihnya berdasarkan pakem balungan tadi. Jumlah naskah pakem balungan ini dalam khasanah kesusastraan Jawa cukup banyak dan sebagian telah diterbitkan, antara lain oleh Balai Pustaka, dilengkapi dengan ilustrasi tokoh-tokoh wayang purwa.

Sastra wayang yang ada di dalam khasanah kesusastraan modern Jawa Baru kebanyakan berupa transformasi dari sumber-sumber sastra Jawa Kuna. Proses transformasi tersebut terjadi setelah para sastrawan yang menggubahnya didapat dari sumber kuno itu. Karya gubahan itu merupakan tanggapan dirinya at as karya sastra yang dijadikan sumber karyanya. Gubahan itu ada yang sepenuhnya berinduk pada sumbernya dan sebagian lainnya hanya terbatas pada hal-hal yang menarik perhatiaannya.

Saduran atau bentuk gubahan baru lainnya sebagai proses transformasi berdasarkan penafsiran dirinya atas teks yang menjadi sumber gubahannya. Tidak mustahil jika terjadi penyimpangan yang kadang-kadang amat jauh dari sumber aslinya sebagai bentuk resepsi pembaca sesuai dengan kaidah yang berlaku pada zamannya.

Lakon-lakon wayang purwa, yang semula hanya terbatas pada cerita pakem, yang masih dengan ketat berinduk pada sumber ceritanya, misalnya Ramayana, Mahabharata, baik yang tertulis dalam bahasa Jawa Kuna, Jawa Tengahan, maupun Jawa Baru, dalam masa-masa selanjutnya mengalami per- 
kembangan yang sangat pesat. Dengan begitu, lahirlah lakon-lakon gubahan baru yang masih tetap menampilkan tokoh-tokoh utama wayang purwa tetapi dengan garapan yang sangat bervariasi dan dikenal dengan istilah carangan.

Jumlah naskah sastra wayang cukup banyak. Kenyataan ini menunjukkan bahwa peminat dan perhatian masyarakat terhadap sastra wayang. Di kalangan masyarakat Jawa yang belum seberapa mengenal buku-buku cetakan, maka mereka harus menyalin naskah sastra wayang (Prabowo. dkk, 2007:275-277). Berbagai macam jenis wayang yang ada di Indonesia, yaitu wayang kulit, wayang golek Sunda, wayang Betawi, wayang sasak, wayang timplong, wayang krucil, wayang thengul, wayang jemblung, wayang cepak, wayang kancil, wayang beber, wayang orang, wayang topeng, wayang suluh, wayang wahyu, dan lain-lain. Dari sekian banyak jenis wayang, yang paling populer dan mempunyai usia ribuan tahun adalah adalah wayang kulit. Cerita-cerita pokoknya bersumberkan kitab Mahabharata dan Ramayana yang bernafaskan kebudayaan dari filsafat Hindu, India, tetapi telah diserap ke dalam kebudayaan setempat (Walujo, 2000: xi).

\section{Perlengkapan dan Makna Filosofis Pertunjukan Wa- YANG}

Dalam pertunjukan bayang-bayang itu diperlukan berbagai perlengkapan yang memperlancar jalannya cerita yaitu:

\section{Kelir}

Berasal dari akar kata lir sama dengan lar yang mengandung arti terbentang. Jadi kelir berarti sesuatu yang terbentang atau tergelar. Bayangan yang dipertunjukkan tampak pada kelir.

\section{Blencong}

Berasal dari akar kata cang sama dengan cong yang berarti tidak lurus (bandingkan dengan kata mencong, menceng dan lain sebagainya). Hal ini karena blencong adalah lampu yang dipakai dalam pertunjukan wayang yang mempunyai sumbu tidak lurus.

\section{Kothak}

Berasal dari akar kata thak sama dengan thik yang mengandung arti dua benda yang bertemu (gathuk). Jadi kothak adalah tempat untuk menyimpan wayang; kothak tersebut terbuat dari kayu, terdiri dari dua bagian yang dipertemukan tanpa engsel, yaitu bagian wadhah dan bagian "tutup" yang terpisah.

\section{Kepyak}

Berasal dari akar kata pyak sama dengan pyek yang mengandung arti 
bunyi dari dua kata atau beberapa kepingan yang bertemu. Kepyak adalah suatu alat yang terdiri dari 3 atau 4 kepingan tembaga atau kuningan yang dibunyikan dalam pertunjukan wayang dan mengeluarkan bunyi pyak.

\section{Dhalang}

Berasal dari akar kata lang dan mengandung arti selalu berpindah tempat (langlang). Dhalang adalah orang yang memainkan pertunjukan wayang kulit. Dalam melaksanakan pekerjaannya, ia selalu berpindah tempat, yaitu mendalang di tempat yang satu kemudian mendalang lagi di tempat lain.

Manusia hidup dari lahir sampai meninggal tidak lepas dari 3M, yaitu metu, manten, dan mati; atau masa kehamilan, kelahiran dan masa bayi, masa kanakkanak, remaja, masa dewasa (perkawinan, keluarga), masa kematian (Supadjar, 1985: 194). Pertunjukan wayang purwa apabila dicermati menggambarkan filsafat hidup manusia mulai dari proses kelahiran sampai kematian secara runtut.

Dimulai dengan gunungan yang tidak berada di tengah-tengah kelir maka barulah ada gerak, yang berarti bahwa ada kehidupan, yaitu bayi akan lahir. Berikut makna filosofis pertunjukan wayang purwa.

\section{Kendhaga pecah}

Gunungan ditarik ke bawah kemudian masing-masing gunungan dipegang dengan tangan kanan dan kiri untuk dipisahkan, yang satu ditancapkan di simpingan kanan dan satunya ditancapkan di simpingan kiri. Dipegangnya gunungan otomatis menyebabkan gunungan tersebut bergerak atau pindah tempat, hal ini melambangkan seorang ibu yang akan melahirkan, perutnya bergerak-gerak karena bayi yang ada dalam kandungan sudah ingin keluar. Pemisahan kedua gunungan tersebut melambangkan pecah atau terbelahnya 'kendhaga'atau selaput pembungkus bayi (lapisan plasenta).

\section{Air kawah}

Dua orang parekan atau emban perempuan yang sama rupa, sama warna bahkan sama segala-galanya. Hal ini melambangkan sebelum bayi lahir pasti didahului dengan pecahnya air kawah yang dalam bahasa Jawa disebut ' $k a k a n g$ kawah'. Dipergunakannya emban perempuan karena perempuan adalah simbol kehalusan.

\section{Sang bayi lahir}

Setelah parekan atau emban keluar, kemudian wayang raja atau pemimpin yang keluar. Jika jejer Ngamarta, maka yang keluar pertama adalah Puntadewa, jika Ngastina maka Duryudana, kemudian adik-adiknya. Jika yang keluar pertama bukan raja maka biasanya adalah pemimpin atau sesepuh. Wayang raja melambangkan seseorang atau anak yang lahir. 


\section{Ari-ari keluar}

Setelah raja keluar, maka segera disusul oleh adik-adiknya. Jika Puntadewa yang keluar maka akan disusul oleh Bima, Arjuna, Nakula atau Sadewa. Hal ini melambangkan setelah bayi keluar maka akan segera disusul oleh ariarinya. Dalam bahasa Jawa, kata ari sama artinya dengan adik (karena hukum Van Der Tuuk, (RDL) misal ada Ruhur, Duhur, dan Luhur).

Menurut Sutardjo (2008: 68-70), pertunjukan wayang semalam suntuk apabila dicermati penuh tontonan 'hiburan', tuntunan 'ajaran', dan tataning urip 'penuh aturan hidup dan kehidupan manusia'. Dalam pertunjukan wayang juga menggambarkan proses kelahiran, masa anak-anak, remaja, dewasa dan kematian. Hal tersebut terlihat dalam setiap adegan pertunjukan wayang, yaitu:

a. Pathet Nem. Periode ini berlangsung dari jam 21.00 sampai dengan jam 00.00 (atau jam 9 malam sampai dengan jam 12 malam). Periode ini melambangkan periode anak-anak. Sesuai dengan suasana tersebut, maka gamelan dan lagu dalam Pathet Nem ini ditandai dengan kayon (gunungan) ditancapkan condong kekiri. Periode Pathet Nem ini dibagi menjadi 6 adegan (jejeran) yaitu: Pertama, jejeran (adegan) raja. Raja setelah selesai bersidang diterima oleh permaisuri untuk bersantap bersama. Jejeran ini melambangkan "bayi yang mulai diterima dan mulai diasuh kembali oleh ibunya". Bayi ketika baru lahir biasanya yang pertama kali merawat adalah dukun, bidan, atau orang lain, bukan ibunya. Hal ini karena sang ibu tentu harus beristirahat dulu setelah tenaganya terkuras pada saat melahirkan. Kedua, adegan Paseban Jawi. Adegan ini melambangkan seorang anak yang sudah mulai mengenal dunia luar kemudian mereka ingin mengenal dan memasukinya, tidak perduli apakah itu baik atau kurang baik. Ketiga, adegan Jaranan (pasukan binatang/gajah, babi hutan). Adegan ini melambangkan watak anak atau seorang anak yang belum dewasa biasanya memiliki watak/sifat seperti binatang, yaitu anak tersebut tidak memeperhatikan at uran yang ada, tetapi hanya memikirkan diri sendiri, egois. Mudah marah jika diejek oleh temannya, merasa paling, dan lain sebagainya. Keempat, adegan Perang Ampyak (menghadapi rintangan). Adegan ini melambangkan perjalanan seorang anak yang sudah beranjak dewasa yang mulai menghadapi banyak kesukaran, hambatan dan rintangan. Namun semua rintangan dan hambatan itu dapat dilalui dengan aman. Kelima, adegan Sabrangan yaitu adegan raksasa. Adegan ini melambangkan seorang anak yang sudah dewasa, tetapi watak-wataknya masih didominasi oleh keangkaraan, emosi, dan nafsu. Pada masa ini, seorang anak sedang ingin diperhatikan segala tingkah lakunya, maka untuk mendapatkan perhatian tersebut kadang mereka melakukan hal yang sebenarnya kurang baik dan membahayakan. Kelima, 
adegan terakhir dari Pathet Nem adalah perang gagal. Maksud dari adegan ini yaitu suatu perang yang belum diakhiri dengan suatu kemenangan atau kekalahan atau hanya berpapasan, atau masing-masing mencari jalan lain. Adegan ini melambangkan suatu tataran hidup manusia masih dalam fase/tataran raguragu, belum mantap, karena belum ada suatu tujuan yang pasti.

b. Pathet Sanga. Periode ini berlangsung dari jam 00.00 sampai dengan jam 03.00 (atau jam 12 malam sampai jam 3 pagi). Periode ini ditandai dengan gunungan yang berdiri tegak di tengah-tengah kelir seperti pada waktu mulai pergelaran. Pathet Sanga ini dibagi menjadi 3 adegan (jejeran) yaitu: Pertama, adegan bambangan, yaitu adegan seorang satria berada di tengah hutan atau sedang menghadap seorang pendeta. Adegan ini melambangkan suatu masa, bahwa manusia sudah mulai mencari guru untuk belajar ilmu pengetahuan. Kedua, perang kembang, yaitu adegan perang antara raksasa Cakil berwarna kuning, Rambut Geni berwarna merah, Pragalba berwarna hitam, Galiuk berwarna hijau, melawan seorang satria yang diikuti oleh punakawan. Adegan ini melambangkan suatu tataran/tingkat, bahwa manusia sudah mulai mampu dan berani memenangkan atau mengalahkan nafsu-nafsu angkaranya (sufiah, aluamah, amarah dan mulhimah). Hampir dalam setiap pertunjukan wayang purwa, keempat raksasa ini selalu muncul dan pasti mati kemudian muncul lagi. Keempat raksasa ini adalah lambang nafsu dalam diri manusia yang tidak akan bisa mati ataupun dibunuh, mereka hanya menghilang untuk sementara waktu dan suatu saat akan muncul kembali. Ketiga, jejer/adegan sintren, yaitu suatu adegan seorang satria yang sudah menetapkan pilihannya dalam menempuh jalan hidupnya. Hidup memang penuh dengan pilihan, dengan tidak memilih pun sebenarnya kita sudah memilih. Seseorang dalam hidupnya kadang bingung ketika harus memilih sesuatu yang dirasa sama baik padahal hanya boleh memilih satu hal. Ketika pikiran sudah tidak mampu untuk berfikir maka biasany meminta pertimbangan seseorangan untuk memberikan arahan, bagaimana baiknya dia harus memilih atau menentukan sikap. Dalam cerita wayang Mahabharata, yang biasanya dimintai petunjuk oleh Pandhawa adalah Semar, Kresna, Abiyasa, Widura dan lain sebagainya. Tokoh-tokoh ini dimintai petunjuk karena sudah dianggap ngerti sakdurunge dumadi, jalma limpad seprapar tamat.

c. Pathet Manyura. Periode ini berlangsung dari jam 03.00 sampai dengan jam 06.00 (atau dari jam 3 pagi sampai jam 6 pagi). Periode ini ditandai dengan gunungan (kayon) condong ke kanan. Adapun Pathet Manyura ini dibagi menjadi 3 adegan/jejeran yaitu: Pertama, jejer manyura. Di dalam adegan ini tokoh utama di dalam lakon/cerita sudah berhasil dan mengetahui dengan 
jelas akan tujuan hidupnya. Mereka sudah dekat dengan sesuatu yang dicitacitakan. Untuk dapat dekat/mencapai citan-citanya, mereka harus senantiasa berdoa dan berusaha tanpa kenal lelah bahkan berani mati demi mencapai tujuannya. Kedua, perang brubuh, yaitu suatu adegan perang yang diakhiri dengan suatu kemenangan dan banyak jatuh korban. Adegan ini melambangkan manusia sudah dapat menyingkirkan segala rintangan dan berhasil menumpas segala hambatan hingga berhasil mencapai tujuan. Dalam adegan ini biasanya Bima melakukan joged tayung. Setelah Bima selesai melakukan joged tayung, maka pertunjukan wayang akan selesai (jika bukan Bima, biasanya dimainkan oleh tokoh lain yang merupakan murid Bathara Bayu). Bima adalah murid sekaligus titisan Bathara Bayu. Bayu artinya angin, angin adalah udara yang bergerak. Angin dalam tubuh manusia adalah nafas. Setelah manusia berhenti bernafas maka otomatis meninggal. Ketiga, tancep kayon. Sebagai penutup dari pergelaran wayang tersebut, diadakan tarian Bima atau Bayu yang berarti angin, nafas. Kemudian gunungan (kayon) ditancapkan di tengahtengah lagu. Adegan yang terakhir ini melambangkan proses maut, jiwa meninggalkan alam fana dan menuju kepada kehidupan alam baka, kekal dan abadi. Sekarang pertunjukan wayang sudah tidak lagi sampai pukul 06.00 tetapi biasanya hanya sampai jam 04.00 karena untuk menghormati mereka yang beragama Islam supaya tetap dapat menunaikan ibadah shalat Subuh.

d. Joged Golek. Adegan ini merupakan adegan terakhir dari seluruh pergelaran wayang, yaitu dalang menarikan/memainkan boneka dari kayu yang disebut golek. Adegan ini melambangkan bahwa para penonton diharapkan mencari sendiri nggoleki apa makna, intisari lakon atau cerita pergelaran wayang semalam suntuk itu yang sesuai dengan harkat dan pengalaman hidupnya masing-masing. Dengan demikian, diharapkan setelah menonton pertunjukan wayang purwa tidak hanya mendapatkan kantuk dan lelah tetapi bisa ngonceki makna yang terkandung dalam pertunjukan tersebut karena makna-makna tersebut lebih banyak pada yang tersirat daripada tersurat.

\section{Simpulan}

Dari pembahasan yang telah dipaparkan di atas, dapat disimpulkan beberapa hal berikut ini. Pertama, adanya banyak adegan dalam wayang yang dipert unjukkan untuk menghibur, juga unt uk menyampaikan pesan-pesan kemanusiaan. Kedua, wayang memiliki makna filosofis pada setiap adegan sehingga ada makna yang tersurat dan tersirat. Pertunjukan wayang purwa apabila dicermati menggambarkan filsafat hidup manusia, mulai dari proses kelahiran sampai kematian secara runtut. 


\section{Daftar Pustaka}

Amir, Hazim. 1997. Nilai-nilai Etis dalam Wayang. Jakarta: Pustaka Sinar Harapan.

Nurgiyantoro, Burhan.1998. Teori Pengkajian Fiksi. Yogyakarta: Gadjah Mada University Press.

Poerwadarminta, W.J.S. 1939. Baoesastra Djawa. Batavia. J.B. Wolters Uitgevers Maatschappij. NV.

Prabowo, Dhanu Priyo. Dkk. 2007. Glosarium Istilah Sastra Jawa. Yogyakarta: Narasi.

Supadjar, Damardjati. 1985. Etika dan Tatakrama Jawa Dahulu dan Masa Kini. Yogyakarta: Direktorat Kebudayaan Departemen P dan K.

Sutardjo, Imam. 2008. Kajian Budaya Jawa. Surakarta: FSSR UNS.

Walujo, Kanti. 2000. Dunia Wayang Nilai Estetis, Sakralitas dan Ajaran Hidup. Yogyakarta: Pustaka Pelajar Offset. 